\section{TECHNICAL EDUCATION OF THE FUTURE}

$\mathrm{D}^{\mathrm{R}}$ R. D. S. ANDERSON, principal of the Birmingham Technical College, recently addressed a meeting of the Birmingham General Branch of the Association of Scientific Workers, outlining his views on desirable changes in technical education in Great Britain.

Technical education, Dr. Anderson said, may be roughly defined as the education required by, and given to, personnel in industry, this personnel ranging from the skilled craftsman to the man doing laboratory development work of the highest character. At present the personnel of industry falls roughly into four groups : unskilled, semi-skilled, skilled and technical staff workers. Before examining the needs of the different groups, one should consider if any change in the grouping is to be expected in the postwar period. Dr. Anderson thinks such a change is to be expected. The increase of mechanization, of automatic processes and control, of scientific in place of empirical bases for much industrial practice, will all increase considerably the number of technical staff workers required. This development will be accompanied by the de-grading of many skilled operations to semi-skilled, and the net result is likely to be a decrease in the number of skilled workers and a corresponding increase in the number of technical staff workers and semi-skilled workers. While many may deplore the diminution in the number of skilled workers, the change really represents an advance.

The teaching institutions are concerned only with the skilled and technical staff workers. In Great Britain, apart from university degree courses, comparatively little special preparation or training is given before entering industry. Both the practical and theoretical training begin after entry, the theoretical training being taken, in the majority of cases, in the form of evening courses. This present system of training is unsatisfactory in three main respects: the system is slow, it is frequently unorganized at the works end, and the evening study imposes a very heavy burden on the young person. Students are frequently engaged on their technical studies right through their early twenties, and as a result of this prolonged period of technical study are prevented from developing an interest in cultural subjects and social affairs. One of the main post-war tasks in technical education should be an endeavour to shorten all forms of technical training. In the case of the skilled worker, this could be done by more systematic training in the works, and in the case of the technical staff worker it might be done by arranging some part of his technical course on a full-time basis, either at the beginning or end of the training period. On the Continent, full-time courses for technical staff workers prior to entering industry have been developed to a considerable extent and have proved of great value in supplying industry with a body of well-trained technicians.

Another post-war problem is concerned with teachers in universities and technical colleges. The quality of instruction in any teaching institution depends first on the teacher, secondly on the equipment, and thirdly on the building. While it is obvious that teachers must be carefully selected initially, very little has been given in the past for what one might call their 'care and maintenance'. The output of new knowledge in all branches of science and tech- nology is so overwhelrning that teachers have the greatest possible difficulty in keeping up to date. Technical teachers therefore require refresher courses to bring them up to date in their subjects, and periodical returns to industry to be brought up to date in industrial practice.

Two other points concerning teaching are that some subjects are best taught by practising specialists, and therefore firms should be prepared to allow senior members of their technical staff to act as parttime lecturers during the day. The other point concerns exchange of teachers. It would have a very stimulating effect if teachers could be exchanged between institutions such as universities and technical colleges, and also with American and Dominion institutions.

One of the problems which is ever present in a teaching institution is that of getting into a syllabus all the subject matter which is required. The boundaries of knowledge are advancing so rapidly in all directions that material has constantly to be added to all technical and scientific syllabuses, causing most serious overloading. Perhaps the best solution for this problem is for the universities and technical colleges not to attempt too much in their normal courses, and then to offer, after graduation, a wide range of special advanced courses for technical men in industry to take as required. If some such action were taken and the normal courses relieved of some of their present congestion, it might be possible to introduce a fow 'liberal' subjects into these courses, and so remove the frequent and merited reproach that technical courses are too narrow.

\section{RELATION OF ACADEMIC TRAINING TO INDUSTRY}

$T$ HE Swiss university journal Schweizerisch Hochschule Zeitung of September 1943 contains some long extracts from a report by Dr. H. Erb which has attracted considerable interest in Switzerland, and may have some bearing on post-war educational problems in other countries. It deals with the old and recurring problem of too many with academic training, a matter which has also exercised the minds of leading educationists elsewhere, notably in Germany a few years ago, when it filled many columns in the Chemische Zeitung, and also in the United States. The pressing needs and special conditions of war have submerged the problem in most countries to-day; but it is likely to emerge with still greater insistence after the War. Dr. Erb, while analysing its special features under Swiss conditions with much detail, does not suggest any very new or striking remedial or preventive measures other than those which have already been frequently urged in Great Britain and America: such, for example, as the warning against excessive concentration on the vocational side of education, at all events in a too narrow or specialized sense; the urgent need for raising the dignity of handiwork, of applying more thoroughly the doctrine of Morris and Kropotkin of mind-training through the hand; and a few generalities briefly dealt with below. So far as Switzerland is concerned, it is thought that more complete statistics and better analytical interpreta. tion thereof, together with a greatly improved central organization for the transfer of university men into suitable openings in industry, are urgently needed. 